\title{
"The Influence of Organisational Culture on Leadership Style in Higher Education Institutions
}

\begin{abstract}
Purpose - This study aims to explore the impact of organisational culture on leadership styles in Nigerian universities. The study utilises cultural dimensions theory (Hofstede's insights) and the social exchange concept as theoretical lenses to examine the phenomena.
\end{abstract}

Design/methodology/approach - Using a qualitative approach, 40 interviews were conducted with senior academics and non-teaching staff working in Nigerian universities.

Findings - The findings reveal hierarchical, patriarchal, servile, and interdependent values as the underlying characteristics of organisation culture, shaping the choice of leadership styles in the management of Nigerian universities. As a result, it emerged from the study that positional, formalised exchanges, paternalism, relational approach, and gendered reactions to leadership were typically adopted in university administration in this context.

Limitations/implications - The study relies on a small qualitative sample size, which makes the generalisation of findings difficult. However, the study provides a good understanding of cultural hegemony, framing leadership styles different to those of western cultures.

Originality/value - The findings of this study help to bridge the research gap concerning the implications of organisational culture, and its influence on leadership behaviours in the SubSaharan African context. Research within this subfield in Africa is rare. Specifically, the study also enriches our understanding of cultural dimensions, informing the leadership methods adopted in higher education institutions.

\section{Introduction}

Over the past three decades, there has been widespread scholarly interest in the interrelationship between leadership and culture. Most recently, a wide array of topical issues, such as global leadership (Jurgen, 2018), cross-cultural leadership (Stephan and Pathak, 2016), and the impact of culture on leadership (Chong et al., 2018) have burgeoned. While these studies have furthered our understanding of leadership theory and practice, research analysis on the application of leadership theories across cultures considers that leadership behaviours and practices are culture-bound (Alves et al., 2006). Significantly, what we know about the nature of leadership in work organisations emanates mostly from research on the western world, while there is a paucity of similar studies from developing countries in Sub-Saharan Africa, where institutional and cultural systems differ from the West. According to Mullins and Christy (2013), some of the cultural perceptions from the West appear around notions of orderly Germans, undisciplined Italians and assertive British workers. This situation gives rise to questions concerning the portability of leadership constructs and concepts from the West to non-western regions. In an attempt to fill this gap in the literature, this study seeks to contextually explore the interconnection between organisational culture (OC) and leadership styles based on qualitative data drawn from Nigerian universities. By answering the following research question, we contribute new insights into this knowledge gap in understanding from a non-western context - What is the prevalent organisational culture shaping leadership styles adopted in university administration? 
Broadly, 'culture' is perceived as socially and generationally transferred. It consists of the customary, value-related, traditional, religious, and behavioural patterns of a particular set of people and is known as the essential root of behaviour and it forms the components of social order (Bulley et al., 2017). For instance, the culture in West African regions (Ghana, Cameroun, Liberia, Benin, Nigeria, etc.) is often described as less egalitarian, more religious, and more collectivist (Ferguson et al., 2008). Collectivists tend to promote cooperation and social relations among groups of people (Hofstede, 1980). The study focuses on Nigeria, the most populous black West African country, with almost 200 million people spread across over 250 ethnic groups (Central Intelligence World Factbook, 2017). Nigerians define themselves as members of a social group (i.e. collectivists). As such, strong ties to and mandatory obligations concerning extended relationships are prioritised far above personal achievements and aspirations among individualistic nations such as the US and UK (Jackson, 2004). The institutionalisation of gender dominance also exists in Nigeria, as men have been socialised to become breadwinners, while women are expected mainly to engage in childcare duties and other domestic affairs (Mordi et al., 2013).

Other everyday traditional features of Nigeria include acceptance of hierarchy, gender inequality, and status differences, especially in the workplace (Ituma et al., 2011). This social context is often perceived as providing the rationale for individual and organisational behaviour in Nigeria (Adegboya, 2013). In other words, the macro-context has tendencies of shaping organisational culture (Sackman, 2006). In assessing the leadership situation, Nigeria is plagued with various problems arising from political instability, a high degree of corruption, economic instability, and weak governance undermining good leadership in the country (Dike, 2001). Despite these socio-economic challenges confronting Nigeria, British colonialism has strongly emphasised educational attainment in Nigeria (Ituma et al., 2011). Thus, this paper seeks to provide insights into the cultural nuances and subtleties of how OC influences leadership styles in Nigerian universities. In so doing, our study is organised as follows: the second section presents perceptions of leadership styles and OC in the literature. This is followed by a brief overview of the study context and the method used to collect and analyse the empirical evidence. Thereafter, the results and discussion of the findings are presented. The final section considers the conclusion, study implications, study limitations, and areas for future research.

\section{Leadership perceptions}

Over the past five decades, leadership has been a fertile area of research, evidenced by the substantial academic and practitioners' literature on the topic (Clark et al., 2009). While there is no agreeable definition of 'leadership' in the literature, and diverse interpretations of the construct space exist (Dickson et al., 2003), leadership may simply be described as a relationship through which an individual or group of persons with authority influences the behaviour and actions of others (Moorcroft, 2005). It also means getting others to follow (Mauri, 2017). Therefore, leadership is incomplete without attention to followers (Hollander, 1980). A significant theory for explaining the nature of the leadership relationship and its influences on the behaviours and actions of followers can be analysed through the lens of social exchange theory (SET). SET's central premise is that the exchange of social and material resources is a fundamental form of human interaction (Mitchell et al., 2012). In an organisational setting, for instance, the exchange is often said to be characterised by mutual trust, loyalty, respect, and obligations that generate reciprocal influence between managers 
and their subordinates (Wang et al., 2005). Thus, the social exchange involves leaders conveying the role expectations to their followers and may even provide incentives to those who satisfy these expectations. Similarly, followers will hold role expectations from their leaders with respect to how they are treated and judging by the rewards they will receive for meeting their leader's expectations (Maslyn et al., 2017). Regardless of the reciprocity rule guiding the leader-follower exchange relations, the underlying feature is the nature of leadership and approach according to which the leader influences the actions of others (Buch et al., 2014).

In theory, the antecedents of most leadership approaches have evolved around three areas: trait, behaviour, and contingency (Yukl, 2006). However, leadership as a behavioural category has drawn significant research focus showcasing the importance of leadership styles. Mullins and Christy (2013) observed that these styles are ways in which leadership functions are carried out, emanating from the ways in which managers typically behave towards their subordinates. Historically, prominent paradigms in leadership research are based on the theories of transformational and transactional leadership styles proposed by Burns (1978) and Bass (1985) respectively. On the one hand, the transformational style requires a leader to inspire and stimulate followers to achieve higher levels of performance, with the end goal of developing followers into leaders (Epitropaki and Martin, 2005). On the other hand, transactional leadership is a management style of controlling, organising, and promoting compliance from subordinates with both reward and punishment framing the exchange processes (Burns, 1978; Bass, 1985). Other well-established leadership styles in the literature are laissez-faire (where the leader delegates power and decision making to followers (Skogstad et al., 2007), authoritarian (sometimes described as autocratic), and shared leadership (which aims to build partnerships, promote joint responsibilities, and be participatory in style (Yukl, 2006). While these leadership styles and many more deconstruct leadership into different behavioural categories, there are consistent views within the literature that the integral factor influencing the choice of leadership styles is the cultural context (Dickson et al., 2012; Schnurr et al., 2017).

Due to increasing globalisation and economic integration among industrialised and even developing nations in trade, education, goods, and services, scholarly interest on the implications of cultural context on leadership practices has strengthened (Northhouse, 2013). As explained above, cross-cultural research on leadership has revealed that there are different cultural endorsements of leadership across cultures (e.g. Steers et al., 2012). For instance, it was found in one study that Americans tend to over-romanticise and idealise their leaders to the extent of even glossing or trying to hide some inconvenient truths about them (Parrillo, 2013). On the contrary, Europeans are known to be less enthusiastic about those in leadership (Mittal and Elias, 2016). Moreover, these western societies are individualistic cultures and tend to promote personal achievements, autonomy, uniqueness, and separateness (Hofstede, 1980). Brodbeck et al. (2000, p. 5) found that in western Europe, for instance, respect for leaders is based on egalitarian values, which means 'achieved status is valued more highly than ascribed status'.

However, in West Africa, specifically Ghana, Cameroun, and Nigeria, the concept of leadership is a function of deep-rooted collectivism displayed in communitarian dispositions (Hofstede, 2001). These societies are typically socialised to give high regard to elders and those with superior status, who are considered as having more wisdom and as being 
custodians of community traditions. Such a leadership position is consistent with the traditional chieftaincy system of governance (Jackson, 2004). Bulley et al. (2014) are of the view that this less than egalitarian nature of rulership has found expressions in the leadership styles used by managers in African organisations, which are often perceived effective by subordinates. More importantly, a pattern of managerial system in Sub-Saharan Africa is said to be underpinned by the well-known Ubuntu leadership philosophy, which is anchored in history on governance, reflecting headship under 'a family atmosphere...philosophical affinity and kinship among and between indigenous people of Africa' (Karsten and Illa, 2005, p. 610). 'Ubuntu' is a term used among the Bantu tribe of South Africa and literally translates as a humane style of leadership based on collective solidarity, morality, and communalities (Okereke et al., 2018). For Wanasika, Howell, Littrell \& Dorfman (2011). Note that the Bantu people though initially normadic, have a community that is hierarchically organised which is led by the king who is chosen based on age, wealth, he must be a heterosexual male and power is ascribed along patrilineal inheritance. The kings job here is essentially to act as a mediator and build consensus in a sense, he is a servant leader (Wanasika et al 2011). This mode of leadership is mirrored in many Nigerian traditional societies. It is important to note that various influences within the colonisation and post colonisation period have changed the current configurations of African leadership styles. Some key influences shaping leadership in Africa as well as in many traditional societies include religion, commerce, globalisation, western education, social class/status, ethnicity, dictatorship, paternalism etc (Mansur, Sobral, \& Goldszmidt, 2017; Lee 2001; Furmańczyk, 2010) As such, this cultural orientation is also a strong determining factor in the formation of perceptions that shape social conduct in organisations in such cultures. Therefore, there is a plausible reason to believe that the dynamics of the leadership practices of a particular workplace will be a function of the OC that persists in such a group or society.

\section{Organisational culture}

Since 'culture' is a collective programming of mindsets showing the perceived differences of members of one group from another (Hofstede, 2001), OC, therefore, is analogous to an organisation's personality and comprises deeply rooted artefacts, creations (e.g. slogans and logos), shared values, and basic assumptions that give unique meaning to organisational membership and guide workplace behaviour (Schein, 2010). Affirming this position, Choi and Scott (2008, p. 34) consider OC as a 'deep and complex part of an organisation that strongly influence organisational members'. Furthermore, the Global Leadership and Organisational Behaviour Effectiveness (GLOBE) project initialled by House et al. (2004), conceptualised OC as 'shared motives, values, beliefs, identities, and interpretations or meanings of significant events that result from common experiences of members of collectives that are transmitted across generations'. In essence, OC is perceived as the relationship between employers and employees influenced by workplace norms and traditions (Sackman, 2006). Accordingly, leaders are perceived as needing a profound understanding of OC, its impact, and its nature (Sharmar and Sharma, 2010). Lok and Crawford (2017:323), OC has various impacts on leaders including influencing how leaders make decisions, set targets, perform various work related activities and how leaders are consciously or unconsciously socialised. They highlight different forms of OC (including network, mercenary, fragmented and communal), perspectives of OC (including integration, differentiation and fragmentation) and different types OC (bureaucratic, supportive and innovative) Lok and Crawford (2017:323). 
Moreover, leadership as a phenomenon, particularly within a workplace context, plays an integral role in OC cultivation (Kargas and Varoutos, 2015).

Instructively, Bass and Avolio (1993, p. 51) argue that an 'organisation's culture develops in large part from its leadership while the culture of an organisation can also affect the development of its leadership'. For instance, the transformational leadership style is associated with positive connotations engendering high levels of motivation, constructive inspiration, and a sense of efficacy among followers (Burns, 1978; Bass, 1985). As such, the cultural propensities of transformational leaders may be enmeshed in higher values for motivation and morality built on a social exchange of mutual elevation and inspirational stimulation between leader and followers. However, the transactional leadership style thrives as a form of social exchange system between leaders and subordinates, according to which compliance from subjects is obtained by means of rewards and sanctions (Suhha et al., 2016). Assumedly, transactional leaders work within an OC that follows protocols, procedures, rules, and regulations guiding such social exchanges. An authoritarian style (sometimes autocratic) is exemplified when absolute power resides in the leader, who exercises total control over decisions and procedures and works tasks with little or no input from group members (De Hoogh et al., 2015). This dictatorial style of leadership may portray an oligarchic OC. Organisational researchers have also highlighted paternalistic leadership as a leadership style that embodies strong discipline, authority with high benevolence (Mansur, et al, 2017:702; Aycan 2006). These landmark theories on leadership styles and their impacts on shaping different OCs have immensely contributed to grounding knowledge on the interface between leadership and OC. However, a vast majority of studies on OC and leadership behaviours have been performed in Western societies. The validity of these findings must be proven by a process of testing their applicability to other cultures.

Thus, the Sub-Saharan African context can provide a fertile test field for OC as a concept originating from the West, given the differences between the individualist and collectivist cultures upheld by the members of these respective societies. Geert Hofstede's original research on the impact of culture on the work values of established that cultural individualism and collectivism are opposite poles (Hofstede, 2001). According to Hofstede, individualist societies emphasise the supremacy of individual goals and personal achievements, while collectivists prioritise group relationships and communal responsibilities. Hofstede further identified power distance (PD) as a cultural dimension: the extent to which a culture accepts and endorses uneven distribution of power and status privileges among members (Hofstede, 1980). According to Hofstede, nations with high PD tend to expect unquestionable obedience and submission towards superiors with acclaimed status and authority. In lower PD countries, people expect and accept power relations that are more democratic and consultative in nature. Additionally, a masculinity/femininity divide was also proposed to portray gender identities as culturally determined by role expectations in different societies. For instance, Hofstede contended that 'a society is called masculine when emotional gender roles are clearly distinct: men are supposed to be assertive, tough, and focused on material success, whereas women are supposed to be to be modest, tender, and concerned with the quality of life' (Hofstede et al., 2010). This is why men in most non-western countries are seen as breadwinners, while women are perceived as home and child carers. Building on the strong foundation of Hofstede's theory, the current study seeks to contextually examine the various types of 
leadership styles in Nigerian universities using the different cultural dimensions (as proposed by Hofstede) to consider how leadership practices in the workplace are influenced by OC.

\section{The study context}

The evolution of universities in Nigeria began with the introduction of western education into the country by foreign Christian missionaries and British colonialists. Even though the development of the Nigerian university system may not have been smooth sailing since its inception, one fundamental success it brought to the nation (especially after independence in 1960) was the abundant opportunities for Nigerians to earn the requisite education necessary for labour market entry both locally and internationally (Otonko, 2012). Thus, the increasing desire for skilled human capital in an already saturated Nigerian labour market coupled with astronomical unemployment rates, heightened corruption, and a problematic political climate in Nigeria is making young people struggle to earn higher education degrees and certificates needed for gainful employment. Moreover, the Nigerian society is known for maintaining long-term commitment to the member groups, be it a nuclear or extended families (Aluko, 2003). This is why parents take-up the responsibility of funding the education of their children and wards in Nigeria.

Despite the rapid expansion of Nigerian tertiary institutions as a result of the liberalisation policy introduced by the democratic government in 1999, which brought about the establishment of numerous public, private, and state-owned universities (Obasi, 2007), the educational sector persistently faces challenges ranging from inadequate funding; student cultism; declining teaching and research standards; deteriorating infrastructure; examination malpractice; and various leadership problems. Daramola and Amos (2016) reiterated the fact that there are diverse leadership categories within the Nigerian university community, namely academics, administrators, non-academics, and student unions. It is essential to note that key academic leadership positions, such as deans of faculties, departmental heads, and other nonteaching leadership roles held by senior non-teaching staff, are integral to a university's survival in Nigeria. While leadership is broadly interpreted as an interpersonal influence that a person in charge exerts in a situation in getting others to follow them, it may often be the influence level of the organisational context and culture that determines the preferred leadership style. Therefore, the present study aims to explore influences of OC on leadership practices in Nigerian universities.

\section{Methodology}

The study draws on a social constructivist design, often collaborative, for learning the importance of a social context. This approach often considers the development of new knowledge emerging from an in-depth understanding of how people construct social realities gathered from richly detailed narratives of lived experiences (Saunders et al., 2012). Given the scarcity of extant studies on leadership in the Nigerian context, an exploratory qualitative approach was considered apposite for eliciting the perspective of the informants and to allow them to describe their experience. Therefore, this research is a case study of some selected Nigerian universities. The case study design is a viable method of inquiry because it affords researchers the opportunity to compendiously explore the meanings, nuances, interpretations, and experiences attached to the daily events and social realities of one or more individuals (Cresswell, 2008). However, generalisation from specific case studies to the general population may be challenging. Nevertheless, the case study strategy is useful for 
highlighting the importance of the context, especially when the boundaries between the phenomenon being studied and the context within which it is studied are blurred (EasterbySmith et al., 2012). In total, 40 participants were interviewed. The sample included senior academics and non-teaching staff in three Nigerian universities. Pseudonyms have been used to represent the names of the interviewees and universities for confidentiality reasons. The demographic characteristics of the sample are specified below.

\section{INSERT TABLE 1 HERE}

As shown in Table 1, three universities located in the south-west region of Nigeria were visited, and formal consent to conduct a field study in each institution was obtained. In Table 1, Public University 1 is one of the oldest universities in Nigeria (founded over 50 years ago) while the two private universities ( $2 \& 3$ ) were established 10 and 12 years ago respectively. The sampling technique adopted was purposive. As part of a wider study, semi-structured interviews were conducted with key officers of each university comprising Deans of Faculties (especially professors), Heads of Departments (mostly senior lecturers), senior registry staff (heads of professional service unit), and heads of library services. Participants were solicited by a combination of existing contacts, referrals, and a snowballing process, while eligibility to participate was based on the leadership position held and the years of work experience: a minimum of 10 years. Participants completed the consent forms and were informed that they had a right to withdraw from the study voluntarily at any stage in the interview for any reason. The semi-structured interviews were conducted individually for about 45-60 minutes. Interview questions focused on understanding the underlying OCs of these institutions that influence the choice of leadership styles. Representative of the questions asked are: (1) What leadership style do you adopt in your day-to-day running of the affairs of your faculty/department/registry? (2) What leadership qualities do you display in getting work done? (3) What is the prevalent OC in your institution? (4) How does this culture influence your leadership style? The questions were intentionally open-ended with prompts used to expand discussion and to further elicit the views of the participants. Probes were developed to clarify and explore key issues in depth and signalling to follow interesting lines of inquiry. All interviews were transcribed verbatim shortly after the interview.

All interviews were audio recorded with the permission of the respondents, using a flexible interview protocol. Theoretical saturation was achieved after completing 35 interviews, but to ensure all themes relevant to the study were covered, five additional confirmatory interviews were conducted. These supplementary interviews were conducted to corroborate the previous interview findings. Thereafter, a thematic analysis procedure (TAP) was used to examine the datasets after transcription of the audio recordings. TAP is a qualitative design used to identify, analyse, and report patterns (themes) within datasets (Braun and Clarke, 2006). In ensuring the trustworthiness of our qualitative study, as proposed by Guba and Lincoln (1994), we meticulously adopted a qualitative coding system, which is a well-known method in a qualitative inquiry. This involved generating codes indexed from the transcribed interviews i.e. engaging in a data reduction process through open coding, which involves analysing textual content and creating 'tentative descriptions' from chunks of data directly addressing the research question (Cresswell, 2008). In TAP, data is fractured and integrated to form conceptual themes grounded in the data. Thus, codes with similar characteristics (underlying ideas) were identified and appropriately collapsed to form a category or theme during our analysis.

The coding and categorisation were first conducted independently by two of the authors and then corroboration given to emerging themes by comparing and discussing individual 
interpretations. There was a high degree of corroboration with only four significant cases of disagreement (this related to the interpretation of implied meaning of some of the participants views) which were resolved by discussion until agreement on all classifications was reached. To further enhance the validity of the data analysis process, we invited two experienced qualitative researchers familiar with the aims of this research to independently review our coding and categories. The researchers independently coded a random sample $(15 \%)$ of the interview transcriptions to assess the reliability of the categorisation scheme. We calculated inter coder reliability using Cohen's (1960) kappa. The result of inter-rater reliability between primary coding and secondary coding (Kappa 0.92) showed a high level of agreement which is well above the minimal threshold (kappa 0.70) suggested by Cohen (1960).

\section{Results}

The research inquiry, themes, samples codes, and illustrative codes are presented in Table 2. Overall, five themes emerged from our findings describing leadership styles. Furthermore, the characteristics of OC were identified as: hierarchical, patriarchal, servile, and interdependent values. In-depth analyses of each area are given below.

\section{Positional style}

In this category, ten academics narrated that their choice of using their position authoritatively is derived from intensifying changes to the work environment in Nigerian universities. This was perceived as propelling the need for senior academics holding leadership positions (such as deans of faculties and heads of departments) to become task oriented when managing academics and non-teaching staff under their headship. In the public university, for instance, some of the deans and heads of departments described the extremely high expectations from university management in ensuring teaching and research standards are not compromised makes some of them act authoritatively. Professors also felt their position as a professor should naturally command the utmost respect and ignite faculty members to action. The following quotations typify the participants' shared views:

As the dean of this faculty and a senate member (that is, the highest decision-making body on academic matters in this university), my leadership style entails giving orders and commands to the community of lecturers and scholars in getting our academic and administrative work done, irrespective of our daily heavy workload. So, I ensure all academics and non-teaching staff in my faculty have respect for hierarchy [...] I showcase self-asserting behaviours that prioritise hard work at all times (Participant 2, Public University 1).

For me, my leadership style is characterised by peremptory headship. I am known for my strict supervision of teaching and research activities of all lecturers in the economics department, regardless of the long working hours and tight deadlines to publish papers [...]. Although to a permissive degree, I encourage everyone to contribute in decision making [...]; however, the final implementable decisions reside with me as the head of department. Sometimes I listen to popular opinions from my colleagues in order not to distort our [tightknit] social ties and moral obligation to support one another as a team, [...] I sometimes also discard those opinions I feel are irrelevant and ensure credible pedagogical approaches emphasising practical skill acquisitions in our taught courses are strictly adhered to (Participant 25).

I perceive our organisational culture thrives on a top-down control tradition whereby the Vice-Chancellor is vested with absolute powers to oversee academic programming and research development [...]; so, I adopt a directive style of leadership by setting strict but clear objectives for my faculty staff in line with management decisions (Participant 4). 
These examples indicate that increasing workloads, a hierarchical culture, and bureaucratic tendencies are features necessitating the use of power based on position and title. In Hofstede's (1980) study, with a score of 80\%, Nigeria is rated high in PD. This suggests that Nigerians accept authority bestowed on those within the apex of management (traditionally called 'bosses'). Consequently, university administration is regulated according to the dictates of 'legal rationality' (Weber, 1978). The emphasis here is that those at the lower cadre of employment are mandated to be submissive and obedient to those in organisational leadership. These findings align with those of Heystek (2016), who considered educational leadership in developing countries as sometimes authoritarian in nature and perceived that positional leaders in those contexts often rely solely on their formally defined roles to influence or coerce followers to obey them.

This leadership style is also found in some East Asian countries e.g. Hong Kong, Korea, Japan, and China, where a leader's legitimacy and acceptance are often perceived as contingent on the individual's non-utilitarian qualities (Blunt and Jones, 1997). For example, Whitley (1992, p. 113) reported that 'the virtuocracies of Korea and China ruled because of their superior moral worth, demonstrated by their mastery of the Confucian classics. This meant that they did not need to justify their status by performing some useful function on behalf as a whole, except perhaps maintaining harmony [...]'. This may be different from leadership practices in the West, where high value is given to teamwork, rationality, delegation, and empowerment (Dickson et al., 2003). It is therefore unsurprising that cultural differences play an integral part in creating guidelines and reinforcing preferred leadership styles accepted in one country and rejected by another. Thus, positional leadership behaviours may thrive in Nigeria where the PD is high when compared to some western societies with lower PD indices (Hofstede, 1980).

\section{Formalised exchanges}

Eight respondents were identified as using this type of leadership approach. They described being very formal and keeping to protocols when dealing with their subordinates. The style was found to be transactional in nature and these leaders in the universities were those who valued structure and order among followers. The effectiveness of this style is premised on a social exchange between the leader and their followers, according to which the leader champions compliance through the use of rewards and punishments. As a result, the leadermember exchange is premised on a contractual obligation in which the respondents (i.e. leaders) set goals; monitor and reward performance; and sanction academics and nonteaching staff who fail to meet expectations. For instance, Participant 21 commented:

Speaking metaphorically, a visible leadership style I am known for is 'dangling carrots', which represents recognition and praise I often shower during our monthly faculty board meeting on academics that are showing outstanding competences in the areas of teaching and research output, and I 'wield a stick' by reminding those who are not pulling their weight of the dire consequences of scoring below average during performance management reviews done annually $[\ldots]$

Similarly, Participant 11 stated:

Since our legitimate authority as heads of departments is derived from bureaucratic structures of the university, my leadership style is shaped by our organisational culture, which demands everything we do should be strictly formalised [...]. I follow these protocols and always communicate by email all work tasks and outcomes expected by the university management.

Participant 9 echoed this position: 
Institutional governance in Nigerian universities is, most of the time, centralised, which makes me prefer leading by telling people what to do and ensuring compliance with standards prescribed by top management for the community of teachers and scholars [...]. As the head of department, I closely monitor deviances and correct errors through disciplinary actions and also encourage those complying with the set standards.

Another example is as follows:

What works for me in terms of my leadership approach is to motivate and direct staff of our university primarily through appealing to their own self-interest, which I do by making people comply uncompromisingly with my instructions since they know the benefits of obeying guidelines and the repercussions for deviating from them. This is because the managerial approach to university governance in this institution is based on centralising decision-making, which creates uniformity in the system (Participant 29).

From the findings, the 'carrot and stick approach' is evident in Nigeria, as institutional leaders are clear about their expectations by setting rewards for those who adhere to instructions and sanctioning erring staff. Thus, our findings confirm Bass's (1997) conclusion that there is a level of universality in the transactional leadership paradigm in a wide range of organisations and cultures. Typically, this leadership style is based on a relationship of mutual dependence and a social exchange tradition of 'I will give you this, if you do that' (Mullins and Christy, 2013, p. 385). However, this leadership approach may flourish more in Nigeria because of the pronounced hierarchical OC (see Table 2) found to shape this leadership style, identified as focusing on managing by controlling, organising, and ensuring adherence to tasks through the instrumentality of reward and punishment (Bass, 1981).

\section{Paternalism}

The leadership styles of nine participants conform to paternalism. Narratives from these participants suggest a preference for a leadership style that combines the use of strong authority and shows empathy for others. There is evidence in the participants' comments that Nigerians value leaders who, despite their power and position, are also concerned about the needs and wellbeing of people. The perspectives shared by some of the participants revealed a focus on institutional culture that demands respect for age, seniority, and professional status. These interviewees described that the Nigerian culture practises customary obedience to those 'above' them and espouses values of portraying excessive willingness to serve and please superiors, who in return have the responsibility to make decisions that are in the best interest of their subordinates. The following responses evidence this finding:

Given the unduly complicated administrative protocols and academic cores of this public university, I combine strong discipline and adeptness in my leadership style as I ensure smooth running of the day-to-day administrative activities. With increasing pressure to maintain our status as the best citadel of learning among other Nigerian universities, I assert authority and control with some level of fatherly benevolence as part of our institutional culture when relating to all members of staff (Participant 6).

As Nigerians, you know, our cultural roots indicate that obedience is owed to the leader, mainly by virtue of his or her status [...]. This traditional value influences my style of leadership, which is fashioned towards nurturing to build my work group [...]. I thank God because both the permanent and adjunct lecturers in my department are very submissive and respectful, maybe because of my age (Participant 35). 
By the special grace of God, I use a didactic approach in leading members of my department [...]. As a Christian, I believe in moral uprightness and hard work, which I demand strongly from every departmental staff member. I equally try my best to provide support, guidance, and care in a paternal way so that no one is afraid of approaching me when they need help (Participant 23).

The above findings evidence that paternalistic leadership is associated with the use of control, caring behaviour, moral integrity, and paternal benevolence. Instructively, cross-management literature recognises paternalism as a thriving concept in developing economies in Asia and Africa (Cheng et al., 2004; Ayoko and Hartel, 2006; Jackson, 2016). According to Bolden and Kirk (2009), this is because cultural values shaping leadership and management in SubSaharan Africa, for example, include sharing; the sanctity of commitment; respect for compromises and concessions; deference to higher ranks; good social relations; and an acceptable culture of servility. A similar culture of paternalism also exists in Chinese organisations (Farh and Cheng, 2000). However, this leadership practice has been perceived negatively in western societal contexts, where democratic, consultative, and participative forms of management are more popular (Pellegrini and Scandura, 2008). Additionally, Aycan (2006) argued that the benevolent feature of paternalistic management has been hard for western scholars to comprehend. Martinez (2005) also raised concerns about the use of 'control and care' ingrained in paternalism, which is also difficult for westerners to digest. Furthermore, Jackson (2016) perceived that a leader's care and protection roles may be seen as a violation of privacy in these individualistic societies, where people tend to be selfdirected and autonomous (Hofstede, 2001).

\section{Relational approach}

Further evidence from the study, especially from the non-teaching staff (six participants), revealed preferences for a relational approach, as evidenced in Table 2. These interviewees appear to value collectivism and the Ubuntu style of management. They claimed that in order to attain leadership effectiveness, emphasis should be placed on having a harmonious relationship, humaneness, and collectivist bonds with subordinates. The participants shared their views as follows:

Since we hold cultural values that strongly reflect a concern for others in high esteem, my leadership style is informed by this conventional tradition, as I treat every staff member in the registry as family members who need to be taught that the quality of cordial relationship between leaders and their subordinates goes a long way in influencing the desired performance-related outcomes (Participant 29).

I adopt a people-oriented style of leadership in getting my team (in this bursary department) to carry out their daily work tasks [...]. I do so by establishing trust, establishing mutual respect, and constantly building a rapport with the group members [...]. My close interpersonal relationships even make some of them share with me their private life challenges or family problems (Participant 39).

My style of leadership is humanist in nature, because I believe an organisation is only as good as the people within it [...]. I treat people with dignity and sometimes demonstrate behaviour targeted at contributing positively to sustaining their wellbeing, even if it means sacrificing my own convenience to please them [...]. In this way, I develop a deep spirit of involvement and willingness to work among all my library staff members (Participant 40).

The above quotations indicate that maintaining social harmony and fostering interpersonal relationships significantly impact leadership behaviours in Nigerian universities. In this 
context, a major part of the social fabric of Nigeria is its collectivist culture, according to which individuals develop tight-knit social ties and obligations to support the goals and aspirations of others (Mordi et al., 2013). The findings further highlight Ubuntu as an African humanist philosophy shaping the leadership styles of these participants (Table 2). As seen in the comments of the participants, this philosophy stresses the importance of fostering strong community connections and interdependence, prioritising sharing and caring for others as opposed to self-centred and individualistic projections of the West. In most western countries, individuals are independent and free from relying on others. They rather strive to promote uniqueness and an inherent ability to stand out among others (Hofstede, 2001). On the contrary, Nigerians, as collectivists, seek to define themselves as members of a social group (Ituma et al., 2011). Here, strong ties and mandatory obligations to extended relationships are prioritised far above individual achievements and personal aspirations (Jackson, 2004). This is why reciprocity in building the interests of others and maintaining humane behaviour are key leadership qualities exemplified by these interviewees.

\section{Gendered reactions}

Given the fewer number of women (seven participants) than men in our study (Table 1), there was an institutionalised culture of sexism arising from patriarchal values (see table 2) evidenced in the study. Such culture affects the leadership style adopted by female academics to combat gender stereotypes. In this study, the female participants specifically shared views on how the masculine monopoly on university administration makes them aggressively flaunt their leadership skills and competencies to dismantle gender prejudices and provoke admiration and accolades from others despite that they are women (see Table 2 for narratives). In addition, two others spoke of how they seek to overcome gender stereotypes by relentlessly adopting a leadership approach that encourages higher levels of motivation and commitment among subordinates.

Irrespective of the fact that I am a woman, who men sometimes feel is inferior to them, my leadership approach (as an experienced professor of linguistics) is geared towards inspiring both lecturers and administrative staff in my faculty to achieve remarkable results [...]. I do so by giving them some level of autonomy in decision making, which sometimes makes some of the male professors and lecturers surprised at the level of my dogmatic drive to make people creative and innovative (Participant 34).

Interestingly, Participant 14 commented on how she 'breaks the glass ceiling' by displaying traits typically associated with masculinity, such as aggressiveness, dominance, and competitiveness in enhancing her leadership style, which she claims involves mentoring and empowering the academic community concerning the use of library services.

My leadership style mainly draws on stimulating the learning and development of both staff and students concerning the use of the library. Sometimes, I aggressively generate awareness and elevate the interests of my members of staff in achieving this aim [...]. Men who are part of my crew are sometimes intrigued by how passionate and zealous I can become, just like them (Participant 14).

In a similar vein, participant 24 further claimed that:

Although there appears to be a culture promoting male chauvinism in our university, that hasn't deterred me from showcasing charismatic and visionary leadership qualities that even makes all lecturers under my headship aspire to imitate me (Participant 24). 
The above statements represent feminist accounts of some type of transformational leadership abilities that are described as successfully sustaining women in university leadership positions. The narratives here described processes of engendering higher ideals and values of followers as a way of overcoming feminine stereotypes. Interviewees were emphatic concerning how they deal with gender stereotypes by showcasing behaviours typically ascribed to men (Johnson et al., 2008). Here, masculine behaviours, such as determination, courage, assertiveness, competitiveness, and being a visionary (Fernando, 2012), are explicitly highlighted. This is because Nigeria traditionally operates a social system of patriarchy, where leadership is often associated with masculinity in workplaces (Chukwu and Eluko, 2013). Eboiyehi et al. (2016), found that women (about 29.2\%) are generally underrepresented in academia compared to men (70.8\%) in Nigeria. On the whole, our findings confirm the general notion that women may simply be more inclined to demonstrate an assertive style of leadership because of their innate characteristics to become competitive like their male counterparts (Grant, 1988; Kabacoff, 2001; Morgan, 2004).

\section{Discussion}

In board terms, this study set out to address knowledge gaps in existing African leadership studies by establishing the interrelationship between culture and leadership practices in Nigerian higher education institutions. Despite previous calls to evaluate the cross-cultural applicability of leadership theories largely rooted in US and European ideologies to other contexts (Jackson, 2004), this study seeks to incite scholarly awareness suggesting that people's perceptions and orientations of leadership practices vary in accordance with cultural background and experiences. Therefore, the study revealed the application of some western theories of leadership varies to a large extent according to cultural connotations. More specifically, the paper examined the influence of OC on choices of leadership styles adopted in the administration of Nigerian universities. The participants' comments presented herein have evidenced the rich context underlying those abstract cultural terms and have brought out the vivid, lived experiences of the four different characteristics of OC i.e. hierarchical, patriarchal, servile, and interdependent values shaping the five typologies of leadership styles. From the study, some participants' choice of a positional style of leadership is derived from a culture that is highly ingrained in hierarchy and managerialism (Gennard and Judge, 2011). Managerialism as a capitalist ideology is anchored on promoting the self-interest of managers and thrives on a culture that is largely authoritarian, non-participatory, and hierarchical (Kikauer, 2015). As such, the managerialist system of leadership can be considered as necessitating the adoption of an authoritative leadership style by some participants for the purpose of tightening their control over the academic labour process. Furthermore, the description of Nigerian employees as excessively submissive and obedient to superiors coupled with the culture of high PD contributes to shaping the authoritarian style of leadership in this context (Hofstede, 2001).

Conversely, western scholars (e.g. Blunt and Jones, 1997; Mullins and Christy, 2013; Johnson, 2015) have argued that in contemporary work situations, it is becoming increasingly difficult for managers to solely rely on the use of their positions in hierarchical structures. To get the best results from subordinates, Johnson (2015) suggests the need for leaders to adopt a more egalitarian approach similar to those of Scandinavian countries (e.g. Denmark, Sweden, and Norway) where the desire to appear as a 'big chief' seems to be totally removed from the behaviour of people in management positions. Likewise, further findings from our study reveal the prevalent $\mathrm{OC}$ of hierarchy framing the use of formalised exchanges. It was found that this leadership behaviour was transactional in nature. This style takes its root in an earlier leadership concept known as the path-goal theory (House, 1971). The theory specifies that an 
employee's motivation is dependent on the belief that increased effort to attain 'an improved performance will be successful, and expectations of that improved performance will be instrumental in obtaining positive rewards and avoiding negative outcomes' (Mullins and Christy, 2013, p. 383). Our findings however, show the extent to which culture provides a frame of reference and guide for a transactional leadership style adopted by senior academics in Nigerian universities. Since the OC is characterised by some level of autocracy where subordinates display a high regard for superiors and are often reluctant to bypass the chain of command, the social exchange between leader and follower may only be at the behest of the leader's will and caprices in the transactional relationship.

Furthermore, African leaders are perceived as demonstrating a benevolent disposition towards their subordinates because a culture of servility is more pronounced there than in the western context (Kuada, 2010). Our study has found that paternalistic leadership is prevalent in the Nigerian context, since those in management positions with full authority show fatherly benevolence towards their subordinates in exchange for commitment and dedication (Zoogah and Beugre, 2012; Fanimehin and Popoola, 2013). In the literature on this topic, paternalism as a leadership framework is associated with offering western alternatives to what is perceived as African management of organisations (Jackson, 2016). This system of organisational governance, particularly in Nigeria, is largely related to the extent of male domination, based on higher superior stratum and upholding cultural values where paternal relationships are highly recognised. This is evident in our findings. However, the defects of this style are apparent with respect to the relationship between paternalism and the leadermember exchange. It has been argued herein that since the choice of leadership style may be based on conditions, the leader often has unfettered powers to decide the quality of individual relationships or alliances with subordinates (Pellegrini and Scandura, 2008). While in-group values are integral to paternalistic methods, there may be inclinations to practice nepotism behind a disguise of benevolence. This is the reason why Daramola and Amos (2016) pointed out that university administration in Nigeria sometimes reflects authoritative paternalism, which hinders collegial and transparent governance. As such, the general perception in the literature is that African leaders are grossly ineffective and adapt abysmally to global demands for ethical leadership (Nnabuife, 2010).

Interestingly, our findings unveiled preferences for a relational approach to leadership influenced by cultural features of what Hofstede (1980) referred to as collectivism. Apparently, cultural values in these societies (e.g. Nigeria) are characterised by diffused and mutual obligations in prioritising communality. A similar cultural context is found in Kenya. For instance, Abaya (2016) studied school principals in Kenya and confirmed the existence and high level of dependence on communities and parents for resources needed to run schools in some provinces in south-west Kenya. Being predominantly a collectivistic culture, the Nigerian society is tightly integrated, while leadership practices in this context are a function of a broader social order of manifesting interdependent values (see Table 2). The evidence from our study illustrates leadership behaviours entrenched in promoting harmonious relationships and enacting humanistic management practices rooted in Ubuntu as an African way of life, which provides moral guiding principles shaping leadership functions (Tutu and Allen, 2011). As a concept with African origin, Ubuntu is a call to service in making life humane for others, as evidenced in the relational style of leadership adopted by some participants. Certainly, the style bears some resemblance to the servant leadership theory originally proposed by Robert Greenleaf (1970). According to Greenleaf (1970), the leaderfollower exchange of servant leadership begins with the natural feeling that one wants to serve first, and thereafter, a conscious choice brings the individual to aspire to lead. Thus, the relational style stands to project leadership practices that promote stewardship behaviours for 
university management. Stewardship as an outcome of leadership behaviours certainly enhances a sense of personal responsibility in followers when attention is given to their needs, rather than using authoritative or position-based power as personal fiefdoms (Hernandez, 2008).

One of the most disheartening findings of this study is the gender stereotypes arising from the patriarchal nature of the leadership system in Nigeria. This is evident in the narratives of some of the female participants, highlighting how they act more masculine to combat gender stereotypes. Studies (such as Ogbogu, 2011; Olaogun et al., 2015) have identified the causes of gender inequality in academia and the struggles of academic development of females in the university system caused by the male-dominated mode of governance in Nigerian higher education institutions. This is confirmed in the present study, where the collected data shows that men clearly outnumber the women in the three universities (see Table 1). However, in diffusing these gender biases, women are inclined to adopt a leadership style that appears inspirational in nature. Eagly and Johnson (1990) perceives gender stereotypic expectations as, hypothetically, a reason for women to exhibit an interpersonal leadership style that values communication, collaboration, and participation in contrast to the masculine mode of management characterised in a task-oriented managerial style.

\section{Conclusion and implications of study}

This study has presented four different characteristics of OC influencing the leadership styles adopted in university administration in Nigeria. As a result, five themes emerged as possible ways of describing leadership styles from the study. Of particular relevance of this paper, however, are a number of persuasive explanations of how leadership is largely informed by context. Accordingly, the study can be said to have highlighted some preliminary alternatives to western notions of leadership, thereby aiming to show how context might be taken into account. Thus, our study findings have important theoretical and practical implications. From a theoretical perspective, the findings of this study are relevant concerning the bi-directional views proposed to exist in the relationship between leadership and OC (Schein, 2010). In this sense, it remains to be seen whether organisational leaders should determine and shape workplace culture or whether OC remains a contingent factor influencing leadership style. The former is identified as a functionalist paradigm where an integral aspect such as culture is treated as an object of managerial decision with emphasis placed on leaders taking the primary responsibility in building OC, regardless of any pre-existing, in-depth fundamental beliefs and values held in such organisations or contexts (Morgeson et al., 2010).

However, the latter perspective is consistent with our findings that a major variable influencing the choice of leadership style is OC, which is sometimes shaped by broader societal norms and traditions (House et al., 2004; Mullins and Christy, 2013). Additionally, Nikčević (2016, p. 191) argued that culture is older than leadership, so leadership represents just one of the 'manifestations and symbols of the culture in which it occurs'. Consequently, the findings of our study provide evidence to support the notion that culture is deep rooted and drives workplace values and, more importantly, leadership behaviours. Therefore, leadership styles are thus reflective of the specific characteristics of the Nigerian context in which individuals in leadership positions operate. Accordingly, our study provides new insights into the fact that different leadership styles employed by university deans, departmental heads, and senior non-teaching staff of Nigerian universities are predominantly shaped by the level of PD, collectivism, and feminine/masculine values (Hofstede, 1980).

From a practical standpoint, it is clear from this study that context is a defining factor of leadership behaviours. A thorough understanding of cultural influences can help change 
leadership styles that tend to hinder effective leadership and management practices in this context. Some studies have suggested that culture might be an integral factor associated with leadership effectiveness (Morgeson et al., 2010; Mittal and Elias, 2016; Mauri, 2017). Culture that emphasis teamwork, group affiliations, coordination and interpersonal relationships have been associated with greater implementation of improved leadership practices (Morgeson et al., 2010). Nevertheless, as we have noted earlier, OC in Nigeria is more focused on higher levels of $\mathrm{PD}$ and cultural conditioning of one's subordinates (Hofstede, 2001). For instance, the inferences made from the study on the dominance of cultural values, such as patriarchy; autocratic or benevolent tendencies are cultural features that can potentially undermine leadership effectiveness in Nigerian educational institutions. This is why Babalola (2005) argued that the poor management style of Nigerian universities has emerged from a lack of higher cultural forms and ethical conduct that can stir institutional leadership on the path to academic excellence through a university system that can sustain development and salutary values. Therefore, it is important for university management teams to appropriately incorporate traditional values in conjunction with leadership styles that promote an environment that fosters positive work engagement and always achieving a winwin situation in leader-followership exchanges. In expressing a candid view about the need for changes in leadership practices in Africa, Kiggundu (1988, p. 226) asserts that "there is an acute shortage of quality leadership in Africa" due to the high focus on "authoritarian, personalised, and politicised" culture of governance which is not in Africa's the best interest.

Therefore, the findings of our study call for leadership practices that initiate, shape, and sustain the construction of a more nurturing, just, and reinforcing workplace culture in Nigerian universities. Kuada (2010) argued that since culture is a dynamic construct, African management culture is capable of changing. There is therefore a need for university leaders and administrators in Nigeria to exhibit more attentiveness to existing cultural values in a bid to change those age-long traditions hindering effective leadership. In so doing, universities should allocate resources to training and development concerning how the required skillsets for leadership success in Nigeria universities can thrive. Some few limitations of this study should also be noted and addressed in future research. For instance, our study is restricted to a collectivist culture and may not be generalised beyond this cultural orientation. Moreover, as this is a qualitative study, the small sample also makes the generalisation of results difficult. To address this issue, future studies could use statistical techniques to test larger representative samples. As a recommendation, it would make an interesting study to investigate similar topics in other universities in other African countries and those with a different cultural background.

\section{References}

Abaya, J. (2016), “School leadership challenges along Kenya's Borabu-Sotik border”, Educational Management Administration \& Leadership, Vol. 44 No. 5, pp. 757-774.

Adegboye, M. (2013), “The applicability of management theories in Nigeria: Exploring the cultural challenge”, International Journal of Business and Social Science, Vol. 4 No. 10, pp. 205-215.

Aluko, M. O. A. (2003), "The impact of culture on organizational performance in selected textile firms in Nigeria”, Nordic Journal of African Studies, Vol. 12 No. 2, pp. 164-179. 
Aycan, Z. (2006), Paternalism: Towards conceptual refinement and operationalization. In U. Kim, K. S. Yang and K. K. Hwang (Eds.), Indigenous and cultural psychology: Understanding people in context, New York: Springer Science, pp. 445-466.

Ayoko, O. B. and Härtel, C. E. J. (2006) "Cultural diversity and leadership: A conceptual model of leader intervention in conflict events in culturally heterogeneous workgroups", Cross Cultural Management: An International Journal, Vol. 13 Iss: 4, pp.345-360.

Babalola, J. B (2005), "Foundation of management: An overview of tertiary educational institutions in Nigeria”, International Journal of Research in Education, Vol. 1 No. 1, pp. 1724.

Bass, B. (1997), "Does the transactional-transformational paradigm transcend organizational and national boundaries?” American Psychologist, Vol. 52: pp. 130-9.

Bass, B. M. (1981), "Personal selling and transactional/transformational leadership”, Journal of Personal Selling and Sales Management, Vol. 17 No. 3, pp. 19-28.

Bass, B. M. (1985), Leadership and performance beyond expectation, New York: Free Press.

Bass, B. M. and Avolio, B. J. (1993), “Transformational leadership: A response to critiques”, in Chemers, M.M. and Ayman, R. (Eds), Leadership Theory and Research: Perspectives and Directions, Academic Press, San Diego, CA. pp. 49-80.

Blunt, P. and Jones, M. L. (1997), "Exploring the limits of Western leadership theory in East Asia and Africa”, Personnel Review, Vol. 26 No.1/2, pp. 6-23.

Bolden, R. and Kirk, P. (2009), “African leadership: Surfacing new understandings through leadership development”, International Journal of Cross Cultural Management, Vol. 9 No. 1, pp. 69-86.

Braun, V., and Clarke, V. (2006), "Using thematic analysis in psychology", Qualitative Research in Psychology, Vol. 3 No. 2, pp. 77-101.

Brodbeck, F. C., Frese, M., Akerblom, S., Audia, G., Bakacsi, S., Bendova, H., et al., (2000), "Cultural variation of leadership prototypes across 22 European countries", Journal of Occupational and Organisational Psychology, Vol. 73, pp. 1-29.

Buch, R., Kuvaas, B., Dysvik, A. and Schyns, B. (2014), "If and when social and economic leader-exchange relationship predict follower work effort”, Leadership and Organisational Development Journal, Vol. 35 No. 8, pp. 725-739.

Bulley, C. A., Osei-Bonsu N. and Rasag, H. A. (2017), “Attributes of leadership effectiveness in West Africa”, AIB Insights, Vol. 17 No. 1, pp. 11-18.

Burn, J. H. (1978), Leadership, New York: Harper \& Row.

Central Intelligence World Factbook (2017), Nigeria economy, available at www.cia.gov/library/publications/the world-factbook/geos/ni.hrml accessed 14th January, 2018.

Cheng, B., Chou, L. and Wu, T. (2004), "Paternalistic leadership and subordinate responses: Establishing a leadership model in Chinese organisations”, Asian Journal of Social Psychology, Vol. 7, pp. 89-117. 
Chio, Y. S. and Scott, D. K. (2008), “Assessing organisational culture using the competing values framework within American Triple-A baseball”, International Journal of Sport Management and Marketing, Vol. 4 No. 1, pp. 33-48.

Chukwu, B. and Eluko, J. (2013), “Theories in Nigerian business organisation”, European Journal of Business and Management, Vol. 5 No. 17, pp. 166-171.

Clark, R. A., Hartline, M. D. and Jones, K. C. (2009), "The effects of leadership styles on hotel employees' commitment to service quality”, Cornell Hospitality Quarterly, Vol, 50 No. 2, pp. 209-231.

Cohen J. A. (1960), “Coefficient of agreement for nominal scales”, Educational and Psychological Measurement Vol. pp.37-46.

Cresswell, J. W. (2008), Research design, qualitative and mixed methods approaches, Thousand Oaks, CA: Sage.

Daramola, A. G. and Amos, T. T. (2016), "Management and leadership in Nigerian universities”, FUTA Journal of Management, Maiden Edition, Vol. 6, pp. 1-16.

De Hoogh, A. H. B., Greer, L. L. and Hartog, D. N. (2015), "Diabolical dictators or capable commanders? An investigation of the differential effects of autocratic leadership on team performance”, The Leadership Quarterly, Elsevier, pp. 1-15.

Dickson, M. W., Hartog, D. N. D., Mitchelson, J. K. (2003), "Research on leadership in a cross-cultural context: Making progress, and raising new questions”, The Leadership Quarterly, Vol. 14, pp. 729-768.

Dike, V. E. (2001). Democracy and political life in Nigeria. Zaria, Nigeria: Ahmadu Bello University Press.

Eagly, A. H. and Johnson, B. T. (1990), Gender and leadership style: A meta-analysis. Psychological Bulletin, Vol. 1 No. 2, pp. 233-256.

Easterby-Smith, M., Thorpe, R. and Jackson, P. (2012), Management Research, 4th ed, London: Sage.

Eboiyehi, C. O., Fayomi, I. and Ebioyehi, F. A. (2016), "From exclusion to discrimination: Gender inequality in the senior management of Nigerian universities", Issues in Educational Research, Vol. 26 No. 2, pp. 182-205.

Epitropaki, O. and Martin, T. (2005), “The moderating role of individual differences in the relation between transformational/transactional leadership perceptions and organizational identification”, Leadership Quarterly Journal, Vol. 16 No. 4, pp.569-589.

Fanimehin, A. O. and Popoola, S. O. (2013), "Effects of career progression, work motivation and leadership styles on job satisfaction of library personnel in the Federal Civil Service of Nigeria”, International Journal of Library and Information Science, Vol. 5 No. 5, pp. 21412537.

Farh, J. L. and Cheng, B. S. (2000), “A cultural analysis of paternalistic leadership in Chinese organisations", in Li, J. T., Tsui, A. S. and Weldon, E. eds, Management and Organisations in the Chinese Context, London: Macmillan. 
Ferguson, J. L., Dadzie, K. Q. and Johnston, W. J. (2008) "Country-of-origin effects in service evaluation in emerging markets: Some insights from five West African countries", Journal of Business and Industrial Marketing, Vol. 23 Issue: 6, pp.429-437

Fernando, W. D. A. (2012), "A social constructionist perspective of gender stereotyping at work: A case of skilled women in Sri Lanka”, Gender in Management: International Journal, Vol. 27 No. 7, pp. 463-481.

Furmańczyk, J. (2010). The cross-cultural leadership aspect. Journal of Intercultural Management, 2(2), 67-82

Gennard, J. and Judge, G. (2011), Managing employment relations, CIPD: London.

Grant, J. (1988), “Women as managers: What can they offer organizations?” Organizational Dynamics, Winter, pp. 56-63.

Hernandez, M. (2008), "Promoting stewardship behaviour in organisations: A leadership model”, Journal of Business Ethics, Vol. 80, pp. 121-128.

Heystek, J. (2016), "Educational leadership and organisational development and change in a developing country”, South African Journal of Education, Vol. 34 No. 4, pp. 1-4.

Hofstede, G. (2001). Culture's Consequences: Comparing Values, Behaviours, Institutions and Organizations across Nations. Thousand Oaks, CA: Sage.

Hofstede, G. (2001). Cultures' consequences: International differences in work-related values. (2edn) London: Sage Publications.

Hofstede, G. H. (1980), Cultures' Consequences: International differences in work-related values, Beverly Hills, CA: Sage Publication.

Hofstede, G. H., Hofstede, G. J. and Minkov, M. (2010), Cultures and organisations: Software of the mind: Intercultural cooperation and its importance for survival, New York: McGraw-Hill.

Hollander E.P. (1980), Leadership and Social Exchange Processes. In: Gergen K.J., Greenberg M.S., Willis R.H. (eds) Social Exchange. Springer, Boston, MA.

House, R. J. (1971), “A path-goal theory of leadership effectiveness”, Administrative Science Quarterly,

House, R. J., Hanges, P. J., Javidan, M., Dorfman, P. W. and Gupta, V., GLOBE Associates (2004), Leadership, culture and organisations: The GLOBE study of 62 societies, Sage Publications Inc., Thousand Oaks, CA.

Ituma, A., Simpson, R., Ovadje, F., Cornelius, N. and Mordi, C. (2011), "Four domains of career success: How managers in Nigeria evaluate career outcomes", The International Journal of Human Resource Management, Vol. 22 No. 17, pp. 3638-3660.

Jackson, T. (2004), Management Change in Africa: A Cross Cultural Perspective, London: Routledge.

Jackson, T. (2016), "Paternalistic leadership: The missing link in cross-cultural leadership studies”, International Journal of Cross Cultural Management, Vol. 16 No. 1, pp. 3-7.

Johnson, C. E. (2015), Meeting the Ethical Challenges of leadership, (5th Ed), Sage Publishing: U.K. 
Jürgen, Deters, (2018), “Global leadership talent selection as an 1ntegrated acquisition Process", in Joyce S. Osland, Mark E. Mendenhall, Ming Li (ed.) Advances in Global Leadership, Emerald Publishing Limited, Vol. 11, pp. 73-96.

Kabacoff, R. J. (2001), Gender differences in organizational leadership. Do men and women lead differently? Briefings Publishing Group.

Kargos, A. D. and Varoutas (2015), "On the relation between organisational culture and leadership: An empirical analysis”, Cogent Business and Management, Vol. 2, pp. 1-18.

Karsten, L. and Illa, H. (2005), "Ubuntu as a key African management concept: Contextual background and practical insights for knowledge application", Journal of Managerial Psychology, Vol. 20 No.7, pp. 607-620.

Kiggundu, M. N. (1988), Africa in Nath, R. (ed.), Comparatve Management: A regional view, Ballinger, Cambridge, MA, PP. 169-243.

Kikauer, T. (2015), What is managerialism? Critical Sociology, Sage, Vol. 41 No. 7-8, pp. 1103-1119.

Kuada, J. (2010), "Culture and leadership in Africa: A conceptual model and research agenda”, African Journal of Economics and Management Studies, Vol. 1 No. 1, pp. 9-24.

Lee, J. K. (2001). Confucian Thought Affecting Leadership and Organizational Culture of Korean Higher Education. Online Submission

Lok, P., \& Crawford, J. (2004). The effect of organisational culture and leadership style on job satisfaction and organisational commitment: A cross-national comparison. Journal of management development, 23(4), 321-338.

Mansur, J., Sobral, F., \& Goldszmidt, R. (2017). Shades of paternalistic leadership across cultures. Journal of World Business, 52(5), 702.

Martinez, P. G. (2005), Paternalism as a positive form of leadership in the Latin American context: Leader benevolence, decision-making control and human resource management practices. In M. Elvira \& A. Davila (Eds.), Managing human resources in Latin America: An agenda for international leaders: 75-93. Oxford, UK: Routledge.

Maslyn, J. M., Schyns, B. and Farmer, S. M. (2017), “Attachment style and leader-member exchange”, Leadership and Organisation Development Journal, Vol. 38 No. 3, pp. 450-462.

Mauri, T. (2017), "Why leadership styles matter", Strategic Direction, Vol. 33 Issue: 1, pp.14.

Mitchell, M. S, Cropanzano, R. and Quisenberry, D. (2012), Social exchange theory, exchange resources and interpersonal relationships: A modest resolution of theoretical difficulties. In K. Tornblom and A. Kazemi (Eds.), Handbook of social resource theory: Theoretical extensions, empirical insights, and social applications, pp. 99-118. New York, NY: Springer.

Mittal, R. and Elias, S. M. (2016), Social power and leadership in cross-cultural context”, Journal of Management Development, Vol. 35 No. 1, pp. 58-74.

Moorcroft, R. (2005), “The one thing you need to know about great managing, great leadership and sustained individual success”, British Journal of Administrative Management, Vol. 10-11, pp.10-12. 
Mordi, C., Mmieh, F. and Ojo, S. (2013), “An exploratory study of manager’s perspective of work life balance in Nigeria: A case analysis of the Nigerian banking sector", Thunderbird International Business Review, Volume 55 No.1, pp. 55-75.

Morgan, M. J. (2004), “Women in a man's world: Gender differences in leadership at the military academy”, Journal of Applied Psychology, Vol. 34 No.12, pp. 2482-2502.

Morgeson, F. P., DeRue, D. S. and Karam, E. P. (2010), Leadership in teams: A functional approach to understanding leadership structures and processes”, Journal of Management, Vol. 36 No. 1, pp. 5-39.

Mullins, L. J. and Christy, G. (2013). Management and organisational behaviour. England: Pearson.

Nikčević, G. (2016), "The influence of organisational culture on leadership - case study of Montenegro”, Technical Gazette, Vol. 23 No. 1, pp. 191-197.

Nnabuife, E. K. N. (2010), "Defining and enforcing ethical leadership in Nigeria”, African Journal of Economic and Management Studies, Vol. 1 Iss: 1, pp.25-41.

Northhouse, P. G. (2013), Leadership: Theory and practice, $6^{\text {th }}$ ed. Sage: Thousand Oaks, CA.

Obasi, I. N. (2007), “Analysis of the Emergence and Development of Private Universities in Nigeria (1999-2006)”, Council for the Development of Social Science Research in Africa, Vol.5 Iss. 2 \& 3, pp.39-66.

Ogbogu, C. O. (2011), “Gender inequality in academia: Evidences from Nigeria”, Contemporary issues in education research, Vol. 4 No. 9, pp. 1-8.

Okereke, C., Vincent, O. and Mordi, C. (2018), "Determinants of Nigerian managers' environmental attitude: Africa's Ubutu ethics versus global capitalism”, Thunderbird International Review, Wiley, pp. 1-14.

Olaogun, J. A., Adebayo, A. A. and Oluyemo, C. A. (2015), "Gender imbalance in the academia in Nigeria”, European Scientific Journal, Vol. 8, special edition, pp. 294-306.

Otonko, J. (2012), "University education in Nigeria: History, successes, failures and the way forward”, International Journal of Technology and Inclusive Education, Vol. 1 No. 2, pp. 4448.

Parrillo, V. (2013), Diversity in America. New York: Routledge.

Pellegrini, E. K. and Scandura, T. A. (2008), "Paternalistic leadership: A review and agenda for future research”, Journal of Management, Vol. 34, pp. 566-593.

Sackman, K. (2006), Success Factor: Corporate Culture, Bertelaman Stiftung, Guetersloh.

Saunders, M., Lewis, P. and Thornhill, A. (2012), Research methods for business students, 6th ed, London, England: Prentice Education Limited.

Schein, E. H. (2010), Organisational culture and leadership, John Wiley \& Sons Inc, San Francisco, CA.

Schein, E. H. (2010). Organisational Culture and Leadership, John Wiley \& Sons: San Francisco, CA. 
Schnurr S., Chan A., Loew J. and Zayts, O. (2017), Leadership and Culture: When Stereotypes Meet Actual Workplace Practice. In: Ilie C., Schnurr S. (eds) Challenging Leadership Stereotypes through Discourse. Springer: Singapore.

Sharma, S. K. and Sharma, A. (2010), Examining the relationship between organisational culture and leadership styles, Journal of the Indian Academy of Applied Psychology, Vol. 36 No. 1, pp. 97-105.

Skogstad, A., Einarsen, S., Torsheim, T., Aasland, M. S. and Hetland, H. (2007), "The destructiveness of laissez-faire leadership behaviour", Journal of Occupational Health Psychology, Vol. 12, pp. 80-92.

Steers, R. M., Sanchez-Runde, C. and Nardon, L. (2012), "Leadership in a global context: New directions in research and theory development”, Journal of World Business, Vol. 47 Iss: 4, pp. 479-482.

Stephan, U. and Pathak, S. (2016), "Beyond cultural values? Cultural leadership ideals and entrepreneurship”, Journal of Business Venturing, Vol. 31 No. 5, pp. 505-523.

Sudha, K. S., Shahnawaz, M. G. and Farhat, A. (2016), "Leadership styles, leader's effectiveness and well-being: Exploring collective efficacy as mediator”, Vision, Vol. 20 No. 2, pp. 111-120.

Tutu, D. M. and Allen, J, (2011), God is not a Christian: And other provocations, Harper One: New York.

Wanasika, I., Howell, J. P., Littrell, R., \& Dorfman, P. (2011). Managerial leadership and culture in Sub-Saharan Africa. Journal of World Business, 46(2), 234-241.

Wang, H., Law, K. S., Hackett, R. D., Wang, D. and Chen, Z. C. (2005), “Leader-Member Exchange as a mediator of the relationship between transformational leadership and followers' performance and organizational citizenship behaviour", The Academy of Management Journal, Vol. 48, No. 3, pp. 420-432.

Weber, M. (1978), Economy and Society. Ed. G. Roth, and C. Wittich. Berkeley: University of California Press.

Yukl, G. (2006), Leadership in organisations ( $6^{\text {th }}$ Ed.). Upper Saddle River, NJ: PrenticeHall.

Zoogah, D. B. and Beugre, C. (2012), Managing organisational behaviour in the African context. Rouledge: New York, NY. 